\title{
Variability within a native stand of blue grama
}

\author{
W.J. MCGINNIES, W.A. LAYCOCK, T. TSUCHIYA, C.M. YONKER, AND D.A. EDMUNDS
}

\section{Abstract}

Considerable variability and patchiness have been observed within sites of native range dominated by blue grama [Bouteloua gracilis (H.B.K.) Griffiths] range at the Central Plains Experimental Range, Weld County, Colorado. Patches containing tall plants of blue grama with many seedstalks were interspersed with patches of short plants with few seedatalks. Differences in plant height were not entirely related to soil properties. Relative differences in plant height among plants collected in the field were maintained when these plants were grown in a greenhouse environment. "Dry spots" (usually 2 to $4 \mathrm{~m}$ in diameter) that contain dark-colored, wilted plants have also been observed during dry, hot weather. We found several differences in soil properties that could be responsible for the dry spots. All differences in soil properties were within the range for the soil series of the experimental site, an Ascalon fine sandy loam (Aridic Argiustoll). Sixty-two plants of blue grama were collected based on their variability from a single pasture, increased vegetatively in the greenhouse, and transplanted into a spaced-plant nursery. In the third growing season following transplanting, mean values for measurements on replicated clones ranged from 202 to 719 reproductive culms per ramet, 25 to $46 \mathrm{~cm}$ height of reproductive culms, 17 to $24 \mathrm{~cm}$ basal diameter, 39 to 93 grams dry matter per ramet, and from 11 June to 20 July for first anthesis. Somatic chromosome numbers were determined for 60 plants and 55 were tetraploids $(4 x=40), 3$ were pentaploids $(5 x=$ 50), and 2 were hexaploids $(6 x=60)$. We concluded that the observed variability and patchineas apparently result from a combination of both genetic and edaphic factors.

Key Words: Colorado, Bouteloua gracilis, genetic, edaphic, Great Plains, shortgrass prairie

Authors are range scientist (retired), USDA-ARS, Fort Collins, Colo.; head, Dept. of Range Management, Univ. of Wyoming, Laramie; professor, Colorado State Univ., Fort Collins; research associate, Colorado State Univ., Fort Collins; and biological technician, USDA-ARS, Fort Collins, Colo. Contribution of USDA-ARS, Crops Research Laboratory, Colorado State Univ., Fort Collins 80523, in cooperation with Colorado Agricultural Experiment Station, Fort Collins. Manuscript accepted 10 May 1988.
McGinnies (1984) measured the effects of thinning blue grama [Bouteloua gracilis (H.B.K.) Griffiths] on forage production at the Central Plains Experimental Range (CPER) and observed considerable plot-to-plot variation and patchiness for which there was no ready explanation. Where patchiness was observed (Fig. 1) some patches had relatively tall seedstalks while on other patches seedstalks were much shorter or largely absent. There were also patches with a high proportion of bare ground. The various patches ranged from 2 to $10 \mathrm{~m}$ in diameter. The patchiness was intensified because these pastures were grazed only during the winter so that all of the current year's growth was present. If the pastures had been grazed during the growing season, the patchiness would have been less obvious.

On other occasions, numerous dry spots ( 1 to $4 \mathrm{~m}$ in diameter) were observed where the blue grama appeared wilted, brown and lifeless. However, the wilted appearance of the plants on these spots disappeared following a substantial rainstorm and reappeared when the soil again dried.

The present sequence of studies reported here was designed to determine the nature and causes of the observed variablity and to evaluate whether this variability resulted from genetic or edaphic causes.

\section{Experimental Area}

The studies were conducted at the Central Plains Experimental Range, Weld County, Colorado. Elevation is $1,630 \mathrm{~m}$ and average annual precipitation is $310 \mathrm{~mm}$. Native vegetation is dominated by blue grama, but sun sedge (Carex heliophila Mack.), sand dropseed [Sprorbolus cryptandrus (Torr.) Gray], red threeawn (Aristida longiseta Steud.), and bottlebrush squirreltail (Sitanion hystrix J.G.Sm.) are also present. Field studies were conducted, and the blue grama genotypes for the spaced-plant nursery were collected on an Ascalon fine sandy loam (Aridic Argiustoll) in NW1/4 Sec. 17, T10N, R65W. The spaced-plant nursery was estab- 


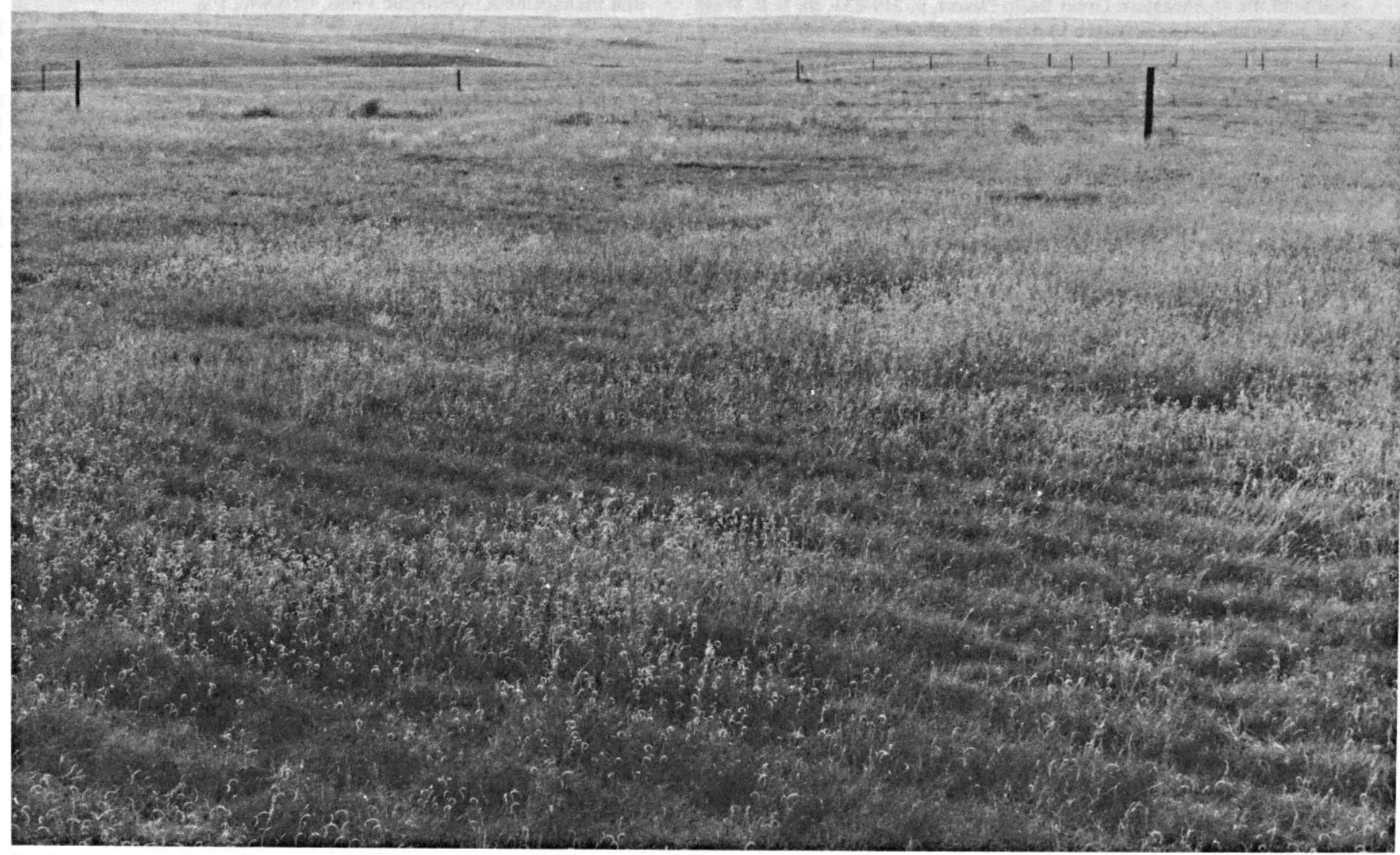

Fig. 1. Patchiness in a chemically thinned stand of blue grama at Central Plains Experimental Range, Colorado. Chemical thinning accentuates the patchy appearance.

lished in $\mathrm{SE} 1 / 4, \mathrm{NE} 1 \frac{1}{4}$, Sec. 18, T10N, R65W where the soil is a Vona sandy loam (Ustollic Haplargid).

\section{Tall and Short Blue Grama}

\section{Methods}

In an area where patches of blue grama with taller seedstalks were intermingled with patches containing shorter seedstalks, 13 10-cm-diam. cores were taken from the "tall" seedstalk patches and 13 cores from adjacent (usually within $2 \mathrm{~m}$ ) "short" seedstalk patches in September 1980. The cores were then placed in 15-cm diam. pots and the pots were filled with additional soil from the site. The plants were then grown in the greenhouse under a 15-hour day and $24^{\circ} \mathrm{C}$ temperatures regimen. Seedstalk heights were measured 14 Feb., 20 April, 11 June, and 7 Oct. 1981. Plants were clipped to a 5-cm stubble after each height measurement. A complete liquid fertilizer was added 5 Mar. and 20 Mar. Treatment means were evaluated by analysis of variance.

\section{Results}

The plants from the tall class in the field were consistently, but not always significantly, taller than plants from the short class when grown in the greenhouse (Table 1). Plants in the tall patches in the field grew in soil that was slightly less sandy and contained slightly more total $\mathrm{N}$. In the greenhouse, all plants received sufficient fertilizer to overcome any differences in soil fertility that might have caused differences in height in the field. Consequently, at least part of the difference in height may be due to genetic differences. The relatively smaller difference in height observed on 7 Oct. 1981, in the greenhouse probably was a result of all plants becoming "pot-bound."
Table 1. Height of seedstalks from 13 cores with "short" and 13 cores with "tall" seedstalks when transplanted into a greenhouse in September 1980, and soil characteristics of the cores.

\begin{tabular}{lccc}
\hline \hline & "Short" & "Tall" & Significance \\
\hline Maximum seedstalk height $(\mathrm{cm})^{1}$ & & & \\
24 February 1981 & 53.5 & 61.1 & 0.10 \\
20 April 1981 & 56.0 & 63.8 & 0.05 \\
11 June 1981 & 40.5 & 49.9 & 0.01 \\
7 October 1981 & 55.7 & 56.5 & N.S. \\
Soil characteristics & & & \\
Sand $(\%)$ & 80.4 & 75.7 & \\
Silt $(\%)$ & 11.8 & 14.7 & \\
Clay $(\%)$ & 7.8 & 9.6 & \\
Total N $(\mu \mathrm{g} / \mathrm{g})$ & 1305 & 1436 & \\
\hline
\end{tabular}

${ }^{1}$ Plants cut to $5 \mathrm{~cm}$ stubble after each height measurement.

${ }^{2}$ Soil characteristics at location of core collection. In greenhouse, a uniform soil was added to fill the pots.

The difference in height between the tall and the short plants appeared to be relatively greater in the field than in the greenhouse. The patchiness in the field gives the appearance of soil variability, but the greenhouse tests showed that there apparently was also a genetic component to the variability.

\section{First Dry Spot Study}

\section{Methods}

In July, 1981, frequent round or oval "dry" spots 1 to $4 \mathrm{~m}$ in 
Table 2. Soll characteristics of first dry spot atudy, 1983.

\begin{tabular}{|c|c|c|c|c|c|c|}
\hline & \multicolumn{3}{|c|}{ "Dry" depth (cm) } & \multicolumn{3}{|c|}{ "Wet" depth (cm) } \\
\hline & $0.0-7.5$ & $7.5-15.0$ & $15.0-22.5$ & $0.0-7.5$ & $7.5-15.0$ & $15.0-22.5$ \\
\hline $\begin{array}{l}\text { Sand }(\%) \\
\text { Silt }(\%) \\
\text { Clay }(\%)\end{array}$ & $\begin{array}{r}80 \\
11 \\
9\end{array}$ & $\begin{array}{l}77 \\
11 \\
12\end{array}$ & $\begin{array}{l}70 \\
14 \\
16\end{array}$ & $\begin{array}{l}77 \\
13 \\
10\end{array}$ & $\begin{array}{l}72 \\
12 \\
16\end{array}$ & $\begin{array}{l}66 \\
13 \\
21\end{array}$ \\
\hline $\begin{array}{l}\text { Total N }(\mu \mathrm{g} / \mathrm{g}) \\
\mathrm{NaHCO}_{3}(\mu \mathrm{g} / \mathrm{g}) \\
\text { Organic matter (\%) }\end{array}$ & $\begin{array}{l}970 \\
19 \\
0.93\end{array}$ & $\begin{array}{c}860 \\
9 \\
0.80\end{array}$ & $\begin{array}{l}1050 \\
6 \\
0.95\end{array}$ & $\begin{array}{l}1090 \\
16 \\
1.10\end{array}$ & $\begin{array}{l}1030 \\
9 \\
0.94\end{array}$ & $\begin{array}{l}1190 \\
7 \\
0.98\end{array}$ \\
\hline $\begin{array}{lr}\text { Soil moisture (\%) } \\
\text { July } 26 \\
28 \\
\text { Aug. } \quad 3 \\
& 8 \\
& 12 \\
16 \\
\\
23 \\
\\
29 \\
\text { Sep. } & 2 \\
\text { Mean } & \end{array}$ & $\begin{array}{l}8.3 \\
4.7 \\
2.8 \\
5.9 \\
3.6 \\
3.3 \\
2.3 \\
4.2 \\
3.3 \\
4.3\end{array}$ & $\begin{array}{l}8.8 \\
6.3 \\
3.6 \\
6.3 \\
6.4 \\
7.0 \\
5.0 \\
4.8 \\
4.4 \\
5.8\end{array}$ & $\begin{array}{l}8.2 \\
6.5 \\
5.9 \\
6.7 \\
8.3 \\
8.9 \\
6.6 \\
6.7 \\
6.5 \\
7.1\end{array}$ & $\begin{array}{r}11.1 \\
6.5 \\
3.0 \\
8.3 \\
4.4 \\
4.3 \\
3.6 \\
5.0 \\
3.1 \\
5.5\end{array}$ & $\begin{array}{r}11.5 \\
8.7 \\
4.8 \\
9.6 \\
8.7 \\
7.5 \\
5.7 \\
6.2 \\
5.0 \\
7.5\end{array}$ & $\begin{array}{l}9.0 \\
8.6 \\
6.7 \\
9.9 \\
9.9 \\
8.9 \\
8.1 \\
7.8 \\
7.1 \\
8.4\end{array}$ \\
\hline
\end{tabular}

diam. were observed in the pastures. Within the dry spots, the blue grama appeared wilted or brown, but again turned green after a rainstorm. The dry spots were separated by green areas of blue grama 1 to $5 \mathrm{~m}$ wide (referred to as "wet" areas in this paper). On 14 July 1981, 5 dry spots and adjacent wet areas were sampled. The wet areas contained less sand, but more clay, $N$, and soil water than the dry spots. From these preliminary data, it was hypothesized that the cause of the dry spots was an edaphic factor, and the dry spots were staked for future study. In 1983, soil water was measured gravimetrically on 10 days between $16 \mathrm{July}$ and 2 Sept. at depths of 0.0 to $7.5,7.5$ to 15.0 , and 15.0 to $22.5 \mathrm{~cm}$. Soil samples from these depths were also analyzed for texture, total Kjeldahl $\mathrm{N}, \mathrm{NaHCO}_{3}$ $P$, and organic carbon.

\section{Results}

Soil from the dry spots contained slightly more sand and slightly less clay, $N$, and organic carbon in the surface $15 \mathrm{~cm}$ than did soil from the wet spots (Table 2). Soil moisture was consistently higher in the wet spots than in the dry spots during the period from 26 July to 2 Sept. There was no difference in the rate of drying during the summer in the surface $7.5 \mathrm{~cm}$, but in the 7.5 to $15-\mathrm{cm}$ zone the rate of drying was slower in the wet than in the dry areas. The differences in soil moisture between the wet and dry spots were presumed to be, at least in part, caused by higher amounts of clay and organic carbon in the wet spots. Although soil differences existed, it was not possible to determine if these differences alone could explain the presence of the dry spots. No difference in micro-relief between wet and dry spots could be discerned.

\section{Second Dry Spot Study}

\section{Methods}

Eleven pairs of wet and dry plots $(30.5 \mathrm{by} 30.5 \mathrm{~cm})$ were selected
Table 3. Second dry spot study. Soil characteristics, plant cover, species composition, and herbage production on wet and dry spots, 1985.

\begin{tabular}{lccr}
\hline \hline & Dry & Wet & P value \\
\hline A horizon, N $(\mu \mathrm{g} / \mathrm{g})$ & 1020 & 1310 & 0.022 \\
A horizon, organic $\mathrm{P}_{\mathrm{o}}(\mu \mathrm{g} / \mathrm{g})$ & 7.6 & 10.4 & 0.030 \\
A horizon, organic $\mathrm{OC}(\%)$ & 0.6 & 0.9 & 0.030 \\
Top $10 \mathrm{~cm}$, N $(\mu \mathrm{g} / \mathrm{g})$ & 930 & 1180 & 0.005 \\
Top $10 \mathrm{~cm}$, organic $\mathrm{P}_{\circ}(\mu \mathrm{g} / \mathrm{g})$ & 6.0 & 8.3 & 0.001 \\
Top $10 \mathrm{~cm}$, organic $\mathrm{OC}(\%)$ & 0.6 & 0.8 & 0.009 \\
Top $10 \mathrm{~cm}$, sand $(\%)$ & 74.8 & 69.8 & 0.003 \\
Top $10 \mathrm{~cm}$, silt (\%) & 13.4 & 17.4 & 0.006 \\
20-cm depth, clay (\%) & 20.6 & 25.3 & 0.055 \\
Total cover (\%) & 65.1 & 77.1 & $<0.001$ \\
Cover, blue grama (\%) & 61.8 & 54.3 & 0.270 \\
Cover, sedge (\%) & 2.2 & 10.1 & 0.025 \\
Cover, buffalograss (\%) & 0.3 & 6.8 & 0.255 \\
Bare soil (\%) & 15.0 & 2.1 & $<0.001$ \\
Dry weight (g/plot) & 6.4 & 10.3 & $<0.001$ \\
\hline
\end{tabular}

and sampled in Aug. 1985. Aerial plant cover by species, litter, and bare ground were measured in these plots with a point frame (100 points). Total standing herbage was determined by clipping to ground level and drying.

A $10-\mathrm{cm}$ diam. hydraulically driven probe was used to obtain soil cores in all plots. Horizons were described and soil was saved for subsequent laboratory analyses. Particle size (hydrometer method), total Kjeldahl nitrogen (N), total $\mathrm{NaHCO}_{3}$ phosphorus $(\mathrm{Pt})$, inorganic $\mathrm{NaHCO}_{3}$ phosphorus $(\mathrm{Pi})$, organic phosphorus (Po) by difference (Pt-Pi), and organic carbon (OC) were determined for each horizon. Very fine, fine, medium, coarse and very

Table 4. Number and height of seedstalks, basal diameter, weight per plant, and date of first anthesis for 60 clones of blue grama in a spaced-plant nursery at CPER. ${ }^{1}$

\begin{tabular}{|c|c|c|c|c|c|c|c|c|}
\hline & \multicolumn{4}{|c|}{1984} & \multicolumn{4}{|c|}{1985} \\
\hline & Min & $\operatorname{Max}$ & Mean & SD & Min & $\operatorname{Max}$ & Mean & SD \\
\hline $\begin{array}{l}\text { Number of reproductive culms } \\
\text { Maximum seedstalk height (cm) } \\
\text { Basal diameter (cm) } \\
\text { Plant weight (g) } \\
\text { Date of first anthesis }\end{array}$ & $\begin{array}{c}54 \\
26 \\
8 \\
9 \\
29 \text { June }\end{array}$ & $\begin{array}{r}287 \\
48 \\
17 \\
54 \\
27 \text { July }\end{array}$ & $\begin{array}{r}134 \\
37 \\
13 \\
21 \\
10 \text { July }\end{array}$ & $\begin{array}{r}46 \\
4 \\
2 \\
7 \\
5\end{array}$ & $\begin{array}{r}202 \\
25 \\
17 \\
39 \\
11 \text { June }\end{array}$ & $\begin{array}{c}719 \\
46 \\
24 \\
93 \\
20 \text { July }\end{array}$ & $\begin{array}{r}404 \\
36 \\
20 \\
57 \\
24 \text { June }\end{array}$ & $\begin{array}{r}99 \\
4 \\
2 \\
10 \\
9\end{array}$ \\
\hline
\end{tabular}

'Based on averages for all ramets of each clone alive at date of measurement. 
coarse sand was determined by sieving for the first 2 horizons of the profile, typically the A and BA. Comparison of wet and dry areas was made on the basis of chemical and particle size data as well as thickness of the A horizon, depth to the top of the Bt horizon, depth to lime, solum depth, depth to lithologic discontinuity, and thickness of the Bt horizon. Laboratory analyses for the top $10 \mathrm{~cm}$ of soil, independent of horizons, were also compared, as was percent clay at $20 \mathrm{~cm}$ depth. Differences between wet and dry areas were evaluated by analysis of variance.

\section{Results}

Values for N, Po, and OC were all greater in the wet spots than in the dry spots (Table 3), and these higher values could explain the greater total cover and dry weight in the wet spots than in the dry spots. The wet spots also had less sand and more silt in the top 10 $\mathrm{cm}$ and more clay at $20 \mathrm{~cm}$ than did the dry spots; these differences would tend to increase the water-holding capacity of the wet spots. Most of the roots were concentrated in the top 20 to $30 \mathrm{~cm}$ of soil. The higher percentage of bare ground in the dry spots would increase the rate of evaporation and the higher sand content near the surface would result in lower soil water-holding capacity. Both of these conditions could contribute to the formation of the dry spots. There were no obvious problems within the solum, such as a hardpan or a gravel layer, that might account for the dry spots.

Species composition, based on cover, in the wet spots was $70 \%$ blue grama and $13 \%$ sun sedge. Species composition in the dry spots was $95 \%$ blue grama and only $3 \%$ sun sedge. The significantly higher amount of sun sedge in the wet spots was expected because most sedges tend to favor moist sites. The difference in species composition between wet and dry spots is probably more a reflection of the difference in available soil water than a cause of it.

\section{Spaced Plant Nursery}

\section{Methods}

A high degree of variability was observed among blue grama plants growing in a 7-ha pasture that had never been plowed at CPER. This variability did not appear to result from microsite differences. To evaluate the variabilty among plants, 62 plants were selected from this site. Plants were selected on 10 September 1981 , based on phenotypic variability for such characters as seedstalk height, number of seedstalks, leaf length, leaf color, bunchiness, or general plant appearance. Selected plants were removed as $10-\mathrm{cm}$ diam. soil-plant cores and immediately watered. Because there appeared to be an intermingling of genotypes within a core, each core was washed to remove the soil, and a single tillering sequence was selected to insure that only 1 genotype was being tested. The tillering sequence was then divided and planted in 10 $\mathrm{cm}$ pots and grown in the greenhouse. These ramets were subsequently divided vegetatively to produce enough ramets for 12 replications. The ramets were transplanted from the greenhouse into a spaced-plant nursery in a field at CPER on 28 July 1982. Ramets were planted in a grid with $76 \mathrm{~cm}$ between ramets using a randomized complete block design with 12 replicates. The ramets were allowed to grow undisturbed through 1983. In 1984 and 1985 data were collected on each ramet for number of seedstalks, height of seedstalks, basal diameter, date of first anthesis, and dry matter yield. Soil samples obtained at the time the original clones were collected were analyzed for total $\mathrm{Kjeldahl} \mathrm{N}, \mathrm{NaHCO}_{3} \mathrm{P}$, organic $\mathrm{C}$, and texture. Somatic chromosome numbers of 60 of the clones were obtained from mitotic root-tip cells from ramets grown in the greenhouse.

\section{Results}

Considerable variation was observed among the 60 surviving clones in the spaced-plant nursery. The range in means among the replicated clones for number of reproductive culms, maximum seedstalk height, basal diameter, dry matter yield and date of first anthesis is shown in Table 4. In 1984, jackrabbits grazed some individual ramets differentially early in the season, and this utiliza- tion probably had some effect on the measured characteristics. A rabbit-proof fence was constructed in July 1984 and eliminated this problem. Because essentially no interplant competition was present in this spaced-plant nursery, these results may not necessarily reflect results obtained in a solid sward on rangeland where there would be intensive competition among plants. For example, it is not uncommon in rangeland to see patches of blue grama 1 to $2 \mathrm{~m}$ in diameter where no seedheads are present. In the spaced-plant nursery all clones had seedheads, yet some of the clones came from patches without seedheads on rangeland.

Growth forms differed widely among the clones, but it is difficult to quantify these differences. Variation included tall, tightly bunched plants with few basal leaves, spreading plants with short seedstalks and many basal leaves, and all combinations between. No apparent relationship existed between growth form or size of plant and any of the measured soil factors (texture, level of $\mathbf{N}$ and P) associated with the soil at the spot where the clone was collected.

Somatic chromosome number was determined for the 60 surviving clones. Fifty-five were tetrapoids $(4 x=40), 3$ were pentaploids $(5 x=50)$, and 2 were hexaploids $(6 x=60)$. Fults $(1942)$ reported that the basic chromosome number $(x)$ for blue grama was 7 , but our results show that the basic number was 10 , which agrees with the results reported by Snyder and Harlan (1953). Pentaploids of blue grama have not been previously reported. In the spaced-plant nursery, the pentaploids and hexaploids did not differ in appearance or size from the tetraploids. A more detailed report on the cytogenetics of blue grama will be published elsewhere.

\section{Conclusions}

In many years of observation at CPER, few seedlings of blue grama have been observed, and even fewer are known to have become established (CPER personnel, unpublished). Even in drought-thinned stands, blue grama roots form a dense mat near the soil surface, and competition likely prevents seedlings from becoming established. Consequently, most of the clones collected in the field from which the plants for the nursery were taken likely had been growing there for a very long time. That such a wide variety of blue grama plants would be found in 1 pasture may seem unusual, but Harper (1977) points out that such variability within a stand dominated by a single species is expected. He states that, "The diversity of a plant community is inadequately described by the number and abundance of species within it. A major part of community diversity exists at the intraspecific level....It has indeed been suggested that where the number of species is low (loose species packing) the intraspecific diversity may be higher-a form of compensation." We believe that the blue grama pasture that we sampled was really a mosaic of microenvironments and soil properties significant to plant growth. We should expect, then, that there would be a mosaic of genotypes and polymorphs occupying these diverse ecological niches.

Once we became aware of patchiness, we were able to find it in most stands of blue grama. The patchiness is most easily observed in pastures that have been chemically thinned, and is more obvious in pastures that have not been grazed during the growing season. The dry spots have been observed in a number of locations and were most easily seen late in the summer during dry periods. Patchiness and dry spots appear to be mutually exclusive, and both frequently occur in the same field.

The patchiness observed in our study is attributable to both genetic and edaphic characteristics. Wet spots generally had a more favorable nutrient balance and a slightly higher water holding capacity than the dry spots, but these differences were subtle. Although we believe that the dry spots are caused primarily by edaphic factors, the exact factors involved have not been determined. Further information is needed to explain both the patchiness and dry spot phenomena. We hope that this paper will help to stimulate such research.

There is apparently much more genetic variability within a stand 
of blue grama than was previously supposed. Differences among the geographic sources of blue grama have been reported (Griffiths 1912, Riegel 1940, Snyder and Harlan 1953), but little information is available concerning the variation within a single stand (Samuel 1985).

Variability within a single stand of blue grama is of particular importance to persons doing research on this species. One must consider the effects of patchiness and dry spots on the sample size needed to characterize a stand. Stratification may be one way to approach this problem. When dealing with individual plants, an adequate number must be collected across the mosaic of microenvironments found at a particular range site so that a representative sample of the genetic variability present is acquired. The high level of genetic variability (polymorphs) should benefit the plant breeder interested in developing improved cultivars of blue grama for the Central Great Plains.

\section{Literature Cited}

Fults, J.L. 1942. Somatic chromosome complements in Bouteloua. Amer. J. Bot. 29:45-55.

Grifnths, D. 1912. The grama grasses: Bouteloua and related genera. Contrib. United States Nat. Herbarium. Vol. 14, Part 3, p. 342-428.

Harper, J.L. 1977. Population biology of plants. Academic Press, London. McGinnies, W.J. 1984. Chemically thinning blue grama range for increased forage and seed production. J. Range Manage. 37:412-415.

Riezel, A. 1940. A study of the variations in the growth of blue grama from seed produced in various sections of the Great Plains region. Trans. Kansas Acad. Sci. 43:155-171.

Samuel, M.J. 1985. Growth parameter differences between populations of blue grama. J. Range Manage. 38:339-342.

Snyder, L.A., and J.R. Harlan. 1953. A cytological study of Bouteloua gracilis from western Texas and eastern New Mexico. Amer. J. Bot. 40:702-707. 